\title{
Utilization of Kañawa (Chenopodium pallidicaule Aellen) Flour in Pasta Making
}

\author{
Mariela C. Bustos, ${ }^{1}$ María Isabel Ramos, ${ }^{2}$ Gabriela T. Pérez, ${ }^{1,3}$ and Alberto E. León (iD) \\ ${ }^{1}$ Instituto de Ciencia y Tecnología de los Alimentos de Córdoba (ICyTAC), CONICET-Universidad Nacional de Córdoba, \\ Córdoba, Argentina \\ ${ }^{2}$ Universidad Mayor de San Andrés, Av Villazón 1995, La Paz, Bolivia \\ ${ }^{3}$ Facultad de Ciencias Agropecuarias, Universidad Nacional de Córdoba, Córdoba, Argentina \\ Correspondence should be addressed to Alberto E. León; aeleon@agro.unc.edu.ar
}

Received 19 October 2018; Accepted 29 January 2019; Published 3 March 2019

Academic Editor: Susana Casal

Copyright ( 92019 Mariela C. Bustos et al. This is an open access article distributed under the Creative Commons Attribution License, which permits unrestricted use, distribution, and reproduction in any medium, provided the original work is properly cited.

\begin{abstract}
Kañawa (Chenopodium pallidicaule Aellen) is an Andean crop harvested in Bolivia and Perú. Because of the characteristics and properties of kañawa seed, its flour can be used to replace partially wheat flour in pasta to increase its nutritional value. The objective of this study was to investigate the production of fiber- and protein-enriched pasta made with wheat and kañawa blends. The effect of the substitution level of wheat by kañawa flour on pasta quality was evaluated taking into account the influence of kañawa composition on starch behavior and gluten network formation. Proximal composition, thermal behavior, and pasting properties of kañawa and wheat flours were determined. Pasta was made from wheat flour (control) replacing 10, 20, and 30\% of wheat by kañawa flour from L1 and L2 ecotypes. Water absorption and cooking loss were increased showing the deleterious effect of kañawa flour on pasta quality, but the L1 ecotype showed better performance in cooking properties. Kañawa pasta firmness and chewiness decreased with the kañawa content increase; however, the L1 ecotype did not modify the firmness when 10 and $20 \%$ were included in pasta. Both kañawa flours improved the nutritional quality of pasta, increasing the dietary fiber content and protein quality.
\end{abstract}

\section{Introduction}

Kañawa or kañiwa (Chenopodium pallidicaule Aellen) is an annual herbaceous plant from the Titicaca Lake surrounding area. Nowadays, it is cultivated in small plots in Bolivia, Ecuador, and Perú at elevations of up to $4400 \mathrm{~m}$ in dry desert and semidesert climates. In Bolivia, kañawa is cultivated in La Paz and Oruro districts. Outside the Altiplano, the plant is sporadically cultivated only at very high elevations [1]. The adaptation of a group of plants to a particular environment is considered to be a different ecotype.

Kañawa was used as food by Andean people before the Spanish conquest [2]. The seeds are toasted, ground into flour, and consumed as food or used to make soup, bread, and cakes. Kañawa grain has been identified as a very promising food crop because of its nutritive value, as judged by its protein, lipid, mineral, and dietary fiber contents, as well as by its essential amino acid composition with high lysine content $[3,4]$. Despite its similarity with quinoa and its even higher nutritional value, kañawa consumption is low because South America population preferences are influenced by European nutritional habits [5], although in Bolivia and Peru, it is usually consumed [4]; hence, there are few studies about kañawa.

Pasta is a popular food because of its sensory appeal, versatility, low cost, ease of preparation, and excellent dried storage stability. It is possible to vary the choice of the ingredients involved in the pasta manufacture to obtain a wide range of pasta products. So, it is necessary to evaluate in what way a change in formulation affects cooking properties since these are an important factor that influence the product quality [6]. Several studies have been carried out to improve 
the nutritional quality of pasta where high protein quality flours or dietary fiber [7-9] were added. High-protein plant materials are derived mainly from soybean, pea, lupine, amaranth, quinoa, and chick pea, all of which can be used as isolates and flours or in their concentrated form.

On the basis of available lysine, protein utilization, and protein efficiency ratio, the values for Andean crops such as amaranth and quinoa proteins are definitely higher as compared to cereal grains and are similar to those of casein $[10,11]$. Kañawa is also rich in oil containing mainly unsaturated fatty acids $[4,12]$, and it has a high content of dietary fiber especially of the insoluble fraction [3]. Some authors have reported high antioxidant capacity and phenolic compounds in kañawa, quinoa, and amaranth grains, usually associated with health benefits $[13,14]$. In addition, Kañawa has an advantage with respect to its relative quinoa because it has no antinutritional components as saponin and it can be used directly as food without washing. Despite the nutritional properties of Andean grains, only in the last few years, some studies have been focused on the development of bakery goods $[15,16]$. Only a scarce information has been found regarding the use of Andean crops in pasta making processes, particularly in gluten-free products $[17,18]$.

Because of the characteristics and properties of kañawa seed, its flour can be used to partially replace wheat flour in baked goods and pasta, increasing their nutritional value; however, only the inclusion of flour other than wheat in pasta making will modify the protein-starch matrix responsible for pasta-cooking behavior and texture profile [6]. The aim of this study was to investigate the production of fiber- and protein-enriched pasta made with wheat and kañawa blends. The effect of the substitution level of wheat by kañawa flour on pasta quality was evaluated taking into account the influence of kañawa composition on starch behavior and gluten network formation.

\section{Materials and Methods}

2.1. Materials. Commercial medium-strength wheat flour was provided by a local milling company (Industrias Alimenticias Tiranti SRL, Argentina). Two different ecotypes of Kañawa flour (L1 and L2) were used. L1 and L2 ecotypes came from Quipaquipani and Jalsuri communities of Viacha city, in the Bolivian Central Altiplano, and were provided by the germplasm bank of PROINPA. Grains were milled in a hammer mill to obtain whole flour from each sample that pass through a 60 mesh sieve.

\subsection{Methods}

2.2.1. Flour Composition. Moisture, protein, lipid and ash content of wheat and kañawa flours were determined according to official methods [19]. Total dietary fiber content was determined according to method 32-05 [19] using a multienzymatic kit (Megazyme, Ireland) and total crude fiber by using method 32-10 [19]. Water retention capacity was determined in the three flours following method 56-11 [19]. All analyses were performed in duplicate.
2.2.2. Differential Scanning Calorimetry. Differential scanning calorimetry measurements were performed using a DSC 823 (Mettler-Toledo, Switzerland). Flour samples were weighed into aluminum pans of $100 \mu \mathrm{l}$ capacity, and distilled water was added until the flour/water ratio was $1: 4$. The samples were allowed to equilibrate for $18 \mathrm{~h}$ before analysis. Indium was used to calibrate the DSC, and an empty pan was used as a reference. Pans were sealed and then were heated from $25^{\circ} \mathrm{C}$ to $120^{\circ} \mathrm{C}$ at a rate of $10^{\circ} \mathrm{C} / \mathrm{min}$. Onset temperature (To), peak temperature $(\mathrm{Tp})$, conclusion temperature $(\mathrm{Tc})$, and enthalpy of gelatinization were determined. Heat enthalpy of gelatinization was calculated on dry solid basis.

2.2.3. Pasting Properties (RVA). Pasting properties of kañawa flours and wheat-kañawa flour blends were determined following the standard Newport Scientific Method 1 (STD1). The heating cycle was 50 to $95^{\circ} \mathrm{C}$ in $282 \mathrm{~s}$, holding at $95^{\circ} \mathrm{C}$ for $150 \mathrm{~s}$ and then cooling to $50^{\circ} \mathrm{C}$. The RVA studies were carried out using $3.0 \mathrm{~g}$ of starch and $25 \mathrm{ml}$ of water in an aluminum canister. The parameters recorded were pasting temperature (Tp), peak viscosity (PV), final viscosity (FV), breakdown (BD), and setback (SB).

2.2.4. Pasta-Making. Pasta was made using commercial wheat flour, water, and kañawa flour from two different ecotypes. Kañawa flours were incorporated into recipes by replacing wheat flour in three proportions $(\mathrm{w} / \mathrm{w}): 10,20$, and $30 \%$. An additional sample with no kañawa flour was also prepared as a control. Pasta was prepared from $50 \mathrm{~g}$ of flour, $500 \mathrm{mg}$ of NaCl , and distilled water according to Bustos et al. [4]. Briefly, the dough was sheeted using a laboratory sheeting machine with a final pass through a roll obtaining a $0.90 \mathrm{~mm}$ thick sheet, and then, it was cut through cutting attachment into strips of approximately $2 \mathrm{~mm}$ wide and $15 \mathrm{~cm}$ long. Pasta was then dried in two steps, the first one was $30 \mathrm{~min}$ at $30^{\circ} \mathrm{C}$ without controlling humidity in an air convection drier and the second step was performed at $45^{\circ} \mathrm{C}$ in a humidity-controlled (75\%) drier for $17.5 \mathrm{~h}$. The samples were wrapped in cling-film and stored in airtight containers at room temperature until needed.

\subsection{Pasta Quality Parameters}

2.3.1. Cooking Procedure. All cooking tests were performed in duplicate. Pasta $(4 \mathrm{~g})$ was broken into pieces of $5 \mathrm{~cm}$ and cooked in boiling distilled water $(200 \mathrm{~mL})$. Boiling was maintained for the total cooking period. The optimum cooking time was considered to be the time when the inner white core of the pasta disappeared after cross-cutting it with a razor blade according to AACC [19] at $1 \mathrm{~min}$ intervals. After cooking at optimum time and draining, the samples were analyzed for swelling index, water absorption, textural properties, color, total dietary fiber, and microstructure. Cooking water was used for determination of cooking losses.

Swelling index of cooked pasta was evaluated by drying pasta samples to constant weight at $105^{\circ} \mathrm{C}$, expressed as 
(weight of cooked product $(W 1)$-weight after drying (W2))/weight after drying (W2) [7].

Water absorption of drained pasta was determined as ((weight of cooked pasta (W3) - weight of raw pasta (W4))/ weight of raw pasta $(W 4)) \times 100$ [7].

Cooking loss in the cooking water collected from each sample was determined by evaporation to constant weight in an air oven at $105^{\circ} \mathrm{C}$. The residue was weighed and reported as percentage of the original pasta sample [7].

2.3.2. Texture of Cooked Pasta. To perform a TPA analysis, a Texture Analyser TA.XT2i (Stable Micro Systems, Godalming, UK) equipped with a Windows version of the Texture Expert Software package was used. The TA.XT2i was fitted with a $25 \mathrm{~kg}$ load cell. Samples were collected by soaking in cold water for $20 \mathrm{~s}$, and excess water was removed by lightly patting between paper towels. One sample was placed centrally under an HDP/PFS pasta firmness-stickiness probe, on a flat aluminum platform base. The probe compressed the pasta samples at a rate of $2.0 \mathrm{~mm} / \mathrm{s}$ to $70 \%$ strain, and the probe was retracted and followed by a second compression cycle after $2 \mathrm{~s}$. Five replicates from two different sets of sheeting were analyzed and averaged. The parameters recorded were hardness, chewiness, cohesiveness, springiness, and resilience.

2.3.3. Scanning Electron Microscopy (SEM). The microstructure of transversely fractured cooked pasta was investigated by SEM. Small portions of cooked pasta were cut with a razor blade and fixed in glutaraldehyde for $2 \mathrm{~h}$ and embedded in a graded acetone series $(250,500,750$, and $800 \mathrm{~g} \mathrm{~kg}^{-1}$ ) for $20 \mathrm{~min}$ at each gradation. Finally, they were embedded in pure acetone at three consecutive $20 \mathrm{~min}$ intervals to ensure full dehydration. Samples were dried by critical point. Critical point drying allows acetone removal in $\mathrm{CO}_{2}$ without surface tension force that may distort the sample. Dehydrated samples were coated with gold particles for $4 \mathrm{~min}$. The images were taken using a Jeol 35 CF (Japan) scanning electron microscope with a $6 \mathrm{kV}$ acceleration voltage. The micrographs were taken using $3000 \mathrm{x}$ magnification.

2.4. Nutritional Parameters. Total dietary fiber was determined in cooked and dried pasta samples according to method 32-05 [19]. Two replicates from two different sets of pasta were analyzed.

Total protein of cooked pasta was determined in duplicates by the Kjeldahl method, and the nitrogen conversion factor used was 5.7 for wheat and enriched pasta; values were expressed in dry basis.

2.5. Statistical Analysis. Results were expressed as the mean of two replicates \pm SD. Data were analyzed by ANOVA, and results were compared by Fisher's test at a significance level of 0.05 , while the relationship between measured parameters was assessed by Pearson's test (significance level at $p<0.05$ ). All analyses were performed using the INFOSTAT statistical software.

\section{Results and Discussion}

3.1. Physicochemical Properties of Wheat and Whole Kañawa Flours and Their Blends. The chemical composition of wheat and kañawa L1 and L2 flours was determined, and the results are shown in Table 1. Kañawa flours showed strong differences between ecotypes in protein, ash, lipid, and dietary fiber contents. Both kañawa ecotypes are good sources of fat and dietary fiber. Other authors have reported similar protein, fat, and crude fiber values for kañawa from Peru $[1,3,11,16]$. The high level of fiber (crude and dietary) and ash in both kañawa flours was due to the presence of seed perigonium fragments after milling and sieving. The L2 ecotype has a higher nutritional value because of its higher protein and fiber contents. Water retention capacity (WRC) of both kañawa and wheat flours was determined, and both kañawa flours showed high values according to the high fiber content, while wheat flour presented significantly lower values (Table 1).

3.2. Thermal and Pasting Properties. Pasta cooking quality has shown to be highly affected by starch gelatinization and protein network formation [20]. As a result, amylose content and starch botanical origin, starch damage, and heatmoisture treatment are important for pasta quality [21]. Indeed, any variation in starch properties that has an impact on pasta water uptake, gel consistency, and gluten breakdown capacity may influence pasta quality. In order to assess the effect of kañawa flour on the thermal behavior and pasting properties of wheat starch, DSC and RVA studies were carried out.

Thermograms of wheat and kañawa flours and their blends showed a first peak corresponding to starch gelatinization and a second one from the amylose-lipid complex. Starch gelatinization parameters of wheat and kañawa flours and their blends are shown in Table 2. Kañawa flours presented lower gelatinization temperature (To, Tp, and Te) and enthalpy than wheat. Quinoa starch presented a range of starch gelatinization temperatures (between 57 and $64^{\circ} \mathrm{C}$ ) similar to kañawa [22]. Lindeboom et al. [23] found lower starch gelatinization temperatures and higher enthalpy when analyzing different quinoa starches. In cases where wheat flour was replaced by $20 \%$ and $30 \%$ of kañawa, To, Tp, and Tc were higher than those of wheat despite kañawa flour showed lower gelatinization temperatures. Probably, other kañawa flour components as fiber, protein, and lipid could modify wheat starch behavior. Different studies have proposed that solutes increase gelatinization temperatures of starches [24]. In general, this effect is achieved through their ability to compete with water, thus reducing the water activity of the system, and through starch-solute interactions. Dietary fiber which is highly composed of water-binding macromolecules is competing with starch for water absorption, hence limiting starch swelling and gelatinization resulting in a higher Tp value [25]. In addition, the formation of a complex between amylose and lipids increases gelatinization temperatures (To and Tp) [26]. Differences in 
TABle 1: Physicochemical properties of wheat and whole kañawa flours*.

\begin{tabular}{lcccccc}
\hline Flour & $\begin{array}{c}\text { Moisture } \\
\left(\mathrm{g} \mathrm{kg}^{-1}\right)\end{array}$ & $\begin{array}{c}\text { Protein } \\
\left(\mathrm{g} \mathrm{kg}^{-1}\right)\end{array}$ & $\begin{array}{c}\text { Ash } \\
\left(\mathrm{g} \mathrm{kg}^{-1}\right)\end{array}$ & $\begin{array}{c}\text { Lipid } \\
\left(\mathrm{g} \mathrm{kg}^{-1}\right)\end{array}$ & $\begin{array}{c}\text { Crude fiber } \\
\left(\mathrm{g} \mathrm{kg}^{-1}\right)\end{array}$ & $\begin{array}{c}\text { Dietary fiber } \\
\left(\mathrm{g} \mathrm{kg}^{-1}\right)\end{array}$ \\
\hline Wheat & $123.0^{\mathrm{b}}$ & $131.0^{\mathrm{a}}$ & $9.8^{\mathrm{a}}$ & $9.0^{\mathrm{a}}$ & $3.0^{\mathrm{a}}$ & $\begin{array}{c}\text { WRC } \\
\left(\mathrm{g} \mathrm{kg}^{-1}\right)\end{array}$ \\
Kañawa L1 & $131.6^{\mathrm{c}}$ & $112.5^{\mathrm{a}}$ & $45.5^{\mathrm{c}}$ & $116.7^{\mathrm{c}}$ & $42.6^{\mathrm{b}}$ & $57.0^{\mathrm{a}}$ \\
Kañawa L2 & $98.6^{\mathrm{a}}$ & $164.3^{\mathrm{b}}$ & $25.4^{\mathrm{b}}$ & $98.3^{\mathrm{b}}$ & $50.8^{\mathrm{c}}$ & $164.3^{\mathrm{b}}$ \\
\hline
\end{tabular}

All parameters are expressed on dry basis. Values followed by the same letter within a column are not significantly different $(p>0.05)$.

TABLE 2: Gelatinization parameters of wheat and both kañawa flours (L1 and L2) and their blends.

\begin{tabular}{lcccc}
\hline Sample & $\begin{array}{c}\text { To } \\
\left({ }^{\circ} \mathrm{C}\right)\end{array}$ & $\begin{array}{c}\mathrm{Tp} \\
\left({ }^{\circ} \mathrm{C}\right)\end{array}$ & $\begin{array}{c}\text { Te } \\
\left({ }^{\circ} \mathrm{C}\right)\end{array}$ & $\begin{array}{c}\mathrm{dH} \text { gel } \\
(\mathrm{J} / \mathrm{g} \text { dry solid) }\end{array}$ \\
\hline Wheat & $61.29^{\mathrm{c}}$ & $67.25^{\mathrm{b}}$ & $74.45^{\mathrm{b}}$ & $4.13^{\mathrm{c}}$ \\
L1 & $55.32^{\mathrm{a}}$ & $60.97^{\mathrm{a}}$ & $68.98^{\mathrm{a}}$ & $2.57^{\mathrm{b}}$ \\
L2 & $57.11^{\mathrm{b}}$ & $61.83^{\mathrm{a}}$ & $68.76^{\mathrm{a}}$ & $74.57^{\mathrm{b}}$ \\
L1-10\% & $61.38^{\mathrm{c}}$ & $67.52^{\mathrm{b}}$ & $76.30^{\mathrm{b}}$ & $4.84^{\mathrm{a}}$ \\
L1-20\% & $62.71^{\mathrm{d}}$ & $68.72^{\mathrm{c}}$ & $76.29^{\mathrm{c}}$ & $4.16^{\mathrm{c}}$ \\
L1-30\% & $62.48^{\mathrm{d}}$ & $68.54^{\mathrm{bc}}$ & $75.55^{\mathrm{bc}}$ & $4.38^{\mathrm{cd}}$ \\
L2-10\% & $62.07^{\mathrm{cd}}$ & $68.24^{\mathrm{bc}}$ & $76.30^{\mathrm{c}}$ & $4.54^{\mathrm{d}}$ \\
L2-20\% & $62.51^{\mathrm{d}}$ & $68.54^{\mathrm{bc}}$ & $75.74^{\mathrm{bc}}$ & $4.14^{\mathrm{c}}$ \\
L2-30\% & $62.47^{\mathrm{d}}$ & $68.56^{\mathrm{bc}}$ & $3.82^{\mathrm{c}}$ \\
\hline
\end{tabular}

To: onset temperature; Tp: peak temperature; Te: end temperature; $\mathrm{dH}$ gel: gelatinization enthalpy. Values followed by the same letter within a column are not significantly different $(p>0.05)$.

lipid content and composition between both ecotypes could be the reason for different effects on wheat starch during heating $[12,22]$.

Effects of kañawa substitution on pasting and gelling starch properties of kañawa-wheat blends were studied (Table 3). Viscosity parameters decreased with the level of kañawa flour in blend according to the low pasting values of kañawa flours (Table 3). The high content of dietary fiber of these flours can decrease the viscosity of wheat flour. The incorporation of dietary fiber in the starch-water system produces a reduction of the pasting parameters, particularly peak and final viscosity, due to a water competition between fiber and starch. The reduction of water availability could decrease the initial granule swelling and keep the granule integrity explaining the lower initial viscosity and breakdown [25]. The interferences with intermolecular associations among amylopectin molecules by added fibers have been proposed as an additional factor affecting the pasting behavior of the starch-glucan system [27]. The increment of lipid content when the kañawa level increases in blends can be another explanation for the diminution of all pasting parameters observed. Complexation of starch with endogenous or added lipids may occur when they are heated together; the complex formation reduces water solubility of starch, decreases swelling capacity, and changes the rheological properties of pastes [28].

3.3. Cooking Properties of Kañawa-Enriched Pasta. Cooking properties of pasta made with wheat flour and different kañawa substitution levels are shown in Table 4. Pasta made with kañawa-wheat flour blends showed lower optimum cooking time (OCT) than wheat pasta with no differences between samples with different kañawa
TABle 3: Pasting properties of wheat and kañawa flours and their blends.

\begin{tabular}{lcccc}
\hline Sample & $\begin{array}{c}\text { PV } \\
(\text { RVU })\end{array}$ & $\begin{array}{c}\text { FV } \\
(\text { RVU })\end{array}$ & $\begin{array}{c}\text { BD } \\
(\text { RVU })\end{array}$ & $\begin{array}{c}\text { SB } \\
(\text { RVU })\end{array}$ \\
\hline Wheat & $242.42^{\mathrm{g}}$ & $287.75^{\mathrm{g}}$ & $81.50^{\mathrm{g}}$ & $126.83^{\mathrm{h}}$ \\
L1 & $41.50^{\mathrm{b}}$ & $67.50^{\mathrm{b}}$ & $0.42^{\mathrm{a}}$ & $26.42^{\mathrm{b}}$ \\
L2 & $19.75^{\mathrm{a}}$ & $22.42^{\mathrm{a}}$ & $2.33^{\mathrm{a}}$ & $5.00^{\mathrm{a}}$ \\
L1-10\% & $188.25^{\mathrm{f}}$ & $242.58^{\mathrm{f}}$ & $65.25^{\mathrm{f}}$ & $119.58^{\mathrm{g}}$ \\
L1-20\% & $160.33^{\mathrm{e}}$ & $216.58^{\mathrm{e}}$ & $52.92^{\mathrm{e}}$ & $109.17^{\mathrm{f}}$ \\
L1-30\% & $139.83^{\mathrm{d}}$ & $198.33^{\mathrm{d}}$ & $44.25^{\mathrm{c}}$ & $102.75^{\mathrm{e}}$ \\
L2-10\% & $193.42^{\mathrm{f}}$ & $237.42^{\mathrm{f}}$ & $64.75^{\mathrm{f}}$ & $108.75^{\mathrm{f}}$ \\
L2-20\% & $155.5^{\mathrm{e}}$ & $200.08^{\mathrm{d}}$ & $49.08^{\mathrm{d}}$ & $93.67^{\mathrm{d}}$ \\
L2-30\% & $132.42^{\mathrm{c}}$ & $175.00^{\mathrm{c}}$ & $39.33^{\mathrm{b}}$ & $81.92^{\mathrm{c}}$ \\
\hline
\end{tabular}

PV: peak viscosity; FV: final viscosity; BD: breakdown; SB: setback. Values followed by the same letter within a column are not significantly different $(p>0.05)$.

substitution levels. Water absorption and swelling indexes increased in relation with the content of kañawa in the pasta, with significant differences in water absorption between ecotypes, L2 being the one with the lowest value. This observation agrees with differences observed in water retention capacity (Table 1). Manthey and Schorno [29] and Vignola et al. [30] found greater cooking loss from spaghetti made with whole-grain wheat than from semolina. The inclusion of whole kañawa flour produced a disruption of the gluten matrix by perigonium particles, providing a path for water absorption into the wheat-kañawa pasta that reduced the cooking time and increased water absorption as observed by others in fiber-enriched pasta $[7,8,31]$. According to this, the greater the level of kañawa contents, the higher the cooking loss values (Table 4). When both kañawa ecotypes at the same substitution level were compared, pastas with the L2 ecotype showed a higher cooking loss than L1 pasta; these 
TABLE 4: Cooking properties of wheat pasta and wheat-kañawa pasta.

\begin{tabular}{|c|c|c|c|c|c|c|c|c|c|}
\hline $\begin{array}{l}\text { Pasta } \\
\text { sample }\end{array}$ & OCT (min) & $\begin{array}{l}\text { Water absorption } \\
\left(\mathrm{g} \mathrm{kg}^{-1}\right)\end{array}$ & $\begin{array}{c}\text { Swelling } \\
\text { index }\end{array}$ & $\begin{array}{c}\text { Cooking loss } \\
\left(\mathrm{g} \mathrm{kg}^{-1}\right)\end{array}$ & Firmness $(N)$ & Cohesiveness & Springiness & Chewiness $(N)$ & Resilience \\
\hline Control & 10 & $1360^{\mathrm{a}}$ & $1.94^{\mathrm{a}}$ & $44.0^{\mathrm{a}}$ & $1.21^{\mathrm{c}}$ & $0.70^{\mathrm{d}}$ & $0.87^{\mathrm{d}}$ & $0.74^{\mathrm{e}}$ & $0.10^{c}$ \\
\hline L1-10\% & 7 & $1670^{\mathrm{c}}$ & $2.23^{\mathrm{b}}$ & $59.0^{\mathrm{b}}$ & $1.22^{\mathrm{C}}$ & $0.64^{\mathrm{c}}$ & $0.85^{\mathrm{cd}}$ & $0.66^{\mathrm{d}}$ & $0.08^{\mathrm{b}}$ \\
\hline L1-20\% & 7 & $1730^{\mathrm{d}}$ & $2.33^{\mathrm{c}}$ & $60.5^{\mathrm{b}}$ & $1.27^{\mathrm{c}}$ & $0.61^{\mathrm{b}}$ & $0.84^{\mathrm{c}}$ & $0.65^{\mathrm{d}}$ & $0.08^{\mathrm{b}}$ \\
\hline L1-30\% & 7 & $1810^{\mathrm{e}}$ & $2.60^{\mathrm{d}}$ & $68.8^{\mathrm{c}}$ & $1.06^{\mathrm{a}}$ & $0.59^{\mathrm{ab}}$ & $0.72^{\mathrm{a}}$ & $0.45^{\mathrm{a}}$ & $0.06^{\mathrm{a}}$ \\
\hline L2-10\% & 7 & $1550^{\mathrm{b}}$ & $2.21^{\mathrm{b}}$ & $71.0^{\mathrm{c}}$ & $1.14^{\mathrm{b}}$ & $0.64^{\mathrm{c}}$ & $0.80^{\mathrm{b}}$ & $0.58^{\mathrm{c}}$ & $0.07^{\mathrm{a}}$ \\
\hline L2-20\% & 7 & $1676^{\mathrm{c}}$ & $2.38^{\mathrm{c}}$ & $76.0^{\mathrm{c}}$ & $1.11^{\mathrm{ab}}$ & $0.57^{\mathrm{a}}$ & $0.71^{\mathrm{a}}$ & $0.45^{\mathrm{a}}$ & $0.06^{\mathrm{a}}$ \\
\hline L2-30\% & 7 & $1800^{\mathrm{e}}$ & $2.59^{\mathrm{d}}$ & $88.0^{\mathrm{d}}$ & $1.13^{\mathrm{b}}$ & $0.59^{\mathrm{ab}}$ & $0.78^{\mathrm{b}}$ & $0.52^{\mathrm{b}}$ & $0.06^{\mathrm{a}}$ \\
\hline
\end{tabular}

Values followed by the same letter within a column are not significantly different $(p>0.05)$.

differences can be explained by the higher dietary fiber content of the L2 ecotype as a positive correlation between those parameters $(r=0.86, p<0.05)$.

Pasting parameters such as peak viscosity $(\mathrm{PV})$ correlate negatively with cooked pasta quality measurements, such as cooking loss $(-0.82)$, swelling index $(-0.98)$, and water absorption (-0.97), indicating a high influence of starch pasting on pasta quality. Sissons and Batey [32] found a negative correlation between cooking loss and peak viscosity. Low cooking loss is a desirable property of good quality pasta. High peak viscosity values are usually correlated with high granule breakdown and starch swelling during heating [22]. High swelling of the granules produce greater leaching in the cooking water, and an increase in cooking loss values would be expected. The negative correlation between PV and cooking loss contradicts this fact and suggests that other factors such as fiber of kañawa flour are affecting cooking loss.

Cooking loss is a commonly used predictor of spaghetti cooking performance [6]. Values lower than $8 \mathrm{~g} \mathrm{~kg}^{-1}$ are considered acceptable for good quality pasta.

The main role of wheat gluten is the formation of a network able to hold the pasta components together [33]. In this sense, it is well known that the addition of nongluten flours with a high level of dietary fiber and lipids can dilute gluten protein and weaken pasta structure $[6,34]$.

Considering that textural characteristics of pasta play a main role in consumer's acceptability which preferred firm and nonsticky pasta [35], results from kañawa-enriched pasta are presented in Table 4.

In general, kañawa addition decreased textural parameter values according to the substitution level. However, $10 \%$ and $20 \%$ L1-substituted pasta had similar firmness to the control and higher chewiness values than 10\% and 20\% L2 samples (Table 4). The L2 ecotype produced a stronger detrimental effect on pasta texture than L1 in agreement with the pasting behavior of this ecotype flour. Chewiness, cohesiveness, and resilience correlated positively with peak viscosity $(r=0.80, r=0.93, r=0.87$, respectively), final viscosity $(r=0.75, r=0.88, r=0.80, p<0.05)$, and breakdown $(r=0.78, r=0.90, r=0.83, p<0.05)$, showing the influence of flour pasting characteristic on pasta texture. Those textural parameters also correlated negatively with water absorption $(r=-0.88, r=-0.93, r=-0.95)$ and swelling index $(r=-0.77, r=-0.85, r=-0.85)$. On the other hand, a significant correlation between firmness and pasting was not observed since gluten content is an essential factor that determines pasta firmness [33] and pasting behavior is governed principally by the amount and properties of starch.

3.4. Pasta Microstructure. Micrographs of the transversal section of cooked pasta made with wheat and kañawa flours and wheat blends are shown in Figure 1. At the outer edge of control spaghetti (Figure 1(a)), gelatinized starch closely interacts with protein forming a network that showed some holes, and when kañawa was incorporated, a disrupted network, with bigger and more irregular holes was observed (Figure 1(b)). At the centre of spaghetti, where the hydration during cooking is lower, some ungelatinized starch granules were observed in control (Figure 1(b)) and kañawa-wheat samples (Figure 1(d)). Kañawa-enriched pasta showed disrupted protein matrix with a more irregular structure and with less ungelatinized granules. The protein matrix disruption produced more porous pasta where hydration and starch gelatinization during pasta cooking can occur faster in agreement with lower OCT and higher cooking loss of kañawa-wheat samples.

3.5. Nutritional Quality. The nutritional value of control and kañawa-enriched pasta was evaluated by dietary fiber and protein content of cooked pasta, and results are shown in Table 5.

The protein content of raw pasta decreased with the $30 \%$ substitution of L1 flour and increased with $20 \%$ and $30 \%$ of L2 flour incorporation since the protein content of wheat flour is higher than that of L1 flour and lower than that of L2 (Table 1). When the protein content was measured in cooked pasta, an increment of protein percentage could be observed with respect to raw pasta (Table 5). During pasta cooking, the solid residue was principally amylose; this fact explained the proportional increment of protein after cooking; however, the proportion of water soluble proteins and pericarp fragments loss during cooking is probably smaller than starch [6].

The protein increment in kañawa-cooked pasta was minor than other results [9]. However, this slight rise can be translated in a higher protein quality of this product because of its high lysine content [11].

Kañawa flour improved the dietary fiber content of raw and cooked enriched pasta (Table 5); the amount of fiber loss 


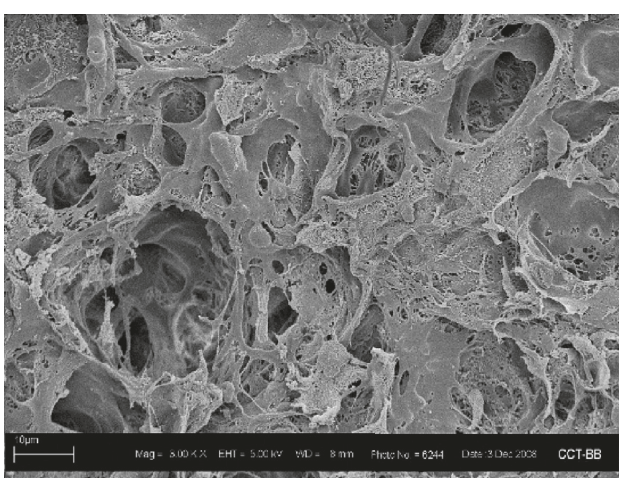

(a)

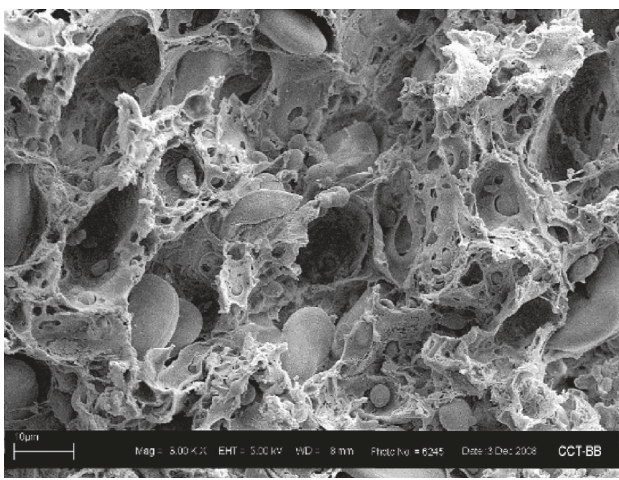

(c)

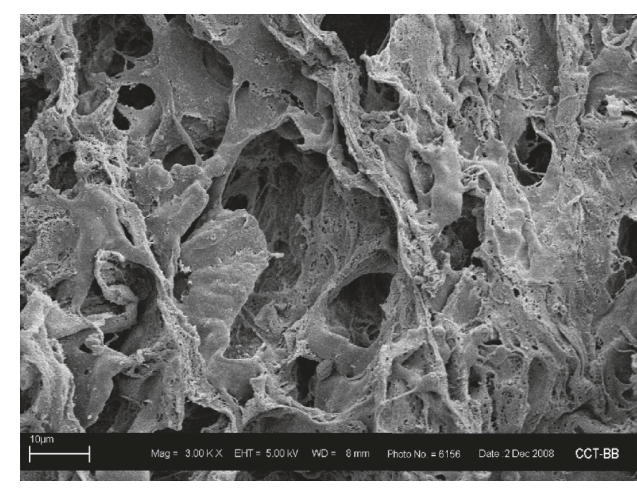

(b)

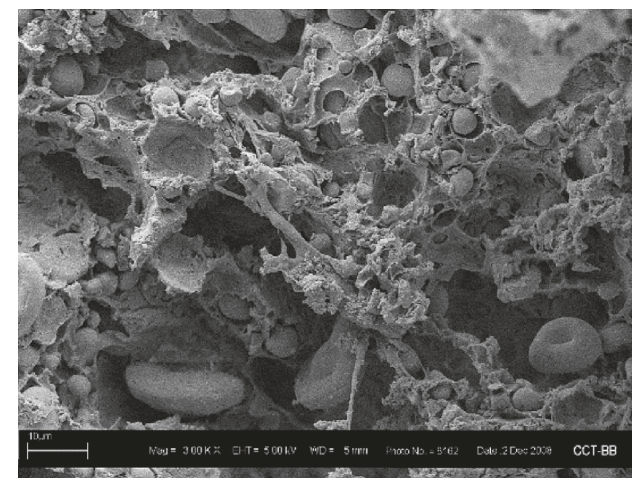

(d)

Figure 1: SEM micrographs of cooked pastas: (a, c) control samples (100\% wheat flour); (b, d) L2-20\% sample (20\% kañawa flour and $80 \%$ wheat flour). ( $a, b)$ Outer edge of strand. (c, d) Centre of the strand.

TABLE 5: Protein and dietary fiber content of raw and cooked pastas.

\begin{tabular}{|c|c|c|c|c|c|c|c|}
\hline & \multicolumn{3}{|c|}{ Protein* $\left(\mathrm{g} \mathrm{kg}^{-1}\right)$} & \multicolumn{3}{|c|}{ Dietary fiber* $\left(\mathrm{g} \mathrm{kg}^{-1}\right)$} & \multirow{2}{*}{$\begin{array}{c}\text { Cooked pasta } \\
\text { moisture } \\
\text { content }(\mathrm{g} / 100 \mathrm{~g})\end{array}$} \\
\hline & $\begin{array}{l}\text { Raw } \\
\text { pasta }\end{array}$ & $\begin{array}{c}\text { Cooked } \\
\text { pasta }\end{array}$ & $\begin{array}{l}\text { Loss } \\
\text { protein }\end{array}$ & $\begin{array}{l}\text { Raw } \\
\text { pasta }\end{array}$ & $\begin{array}{c}\text { Cooked } \\
\text { pasta }\end{array}$ & $\begin{array}{l}\text { Loss } \\
\text { fiber }\end{array}$ & \\
\hline Control & $130.5^{\mathrm{bc}}$ & $144.8^{\mathrm{a}}$ & 14.3 & $57.0^{\mathrm{a}}$ & $53.9^{\mathrm{a}}$ & 3.1 & 66.0 \\
\hline L1-10\% & $128.4^{\mathrm{abc}}$ & $142.8^{\mathrm{a}}$ & 14.4 & $67.6^{\mathrm{b}}$ & $63.9^{\mathrm{b}}$ & 3.7 & 69.0 \\
\hline L1-20\% & $126.3^{\mathrm{ab}}$ & $143.4^{\mathrm{a}}$ & 17.1 & $78.2^{\mathrm{c}}$ & $71.4^{\mathrm{c}}$ & 6.8 & 70.0 \\
\hline L1-30\% & $124.2^{\mathrm{a}}$ & $144.7^{\mathrm{a}}$ & 20.5 & $88.8^{\mathrm{d}}$ & $82.8^{\mathrm{d}}$ & 6.0 & 72.3 \\
\hline $\mathrm{L} 2-10 \%$ & $133.5^{\mathrm{cd}}$ & $151.9^{\mathrm{b}}$ & 18.4 & $77.1^{\mathrm{c}}$ & $60.4^{\mathrm{ab}}$ & 16.7 & 68.8 \\
\hline L2-20\% & $136.4^{\text {de }}$ & $152.8^{\mathrm{bc}}$ & 16.4 & $97.2^{\mathrm{e}}$ & $80.0^{\mathrm{d}}$ & 17.2 & 70.4 \\
\hline L2-30\% & $139.4^{\mathrm{e}}$ & $155.5^{\mathrm{c}}$ & 16.1 & $117.3^{\mathrm{f}}$ & $104.5^{\mathrm{e}}$ & 12.8 & 72.1 \\
\hline
\end{tabular}

*Values are expressed on dry basis. Values followed by the same letter within a column are not significantly different $(p>0.05)$.

during cooking of control and Kañawa L1 pasta samples was considerably lower than in pasta made with kañawa L2. Values of total fiber dietary were similar to those obtained by adding pure resistant starch [8]. The dietary fiber content of a normal serving (dry weight $=100 \mathrm{~g}$ ) of $20 \%$ substitution level pasta would correspond to $20 \%$ in men or $30 \%$ in women of the daily total fiber intake recommended [36].

\section{Conclusion}

High lipid and fiber content of kañawa flour affected the pasting behavior of wheat starch and gluten network continuity of pasta, indicating that the starch-gluten matrix formation is essential to obtain a good pasta quality. However, the substitution of wheat by both kañawa flours improved the nutritional quality of pasta, increasing the dietary fiber content and protein quality of cooked product. The technological properties were modified according to the kañawa ecotype and the substitution level used. Regarding cooking loss values, pasta made with L1 ecotype flour had an acceptable quality when substitution was up to $30 \%$, while firmness was not modified when wheat flour replacement was up to $20 \%$. L2 ecotype affected the cooking properties and texture more strongly producing low quality pasta at $30 \%$ of substitution. Finally, the replacement of $20 \%$ of wheat flour by kañawa flour permits to obtain functional pasta with a satisfactory cooking quality and good nutritional characteristics. 


\section{Data Availability}

The data used to support the findings of this study are included within the article.

\section{Additional Points}

(1) Kañawa-enriched pasta showed some detrimental effect on pasta quality. (2) Wheat flour could be substituted until $20 \%$ to obtain an acceptable pasta quality. (3) Kañawa flours improved dietary fiber content and protein quality of the final product.

\section{Conflicts of Interest}

The authors declare that they have no conflicts of interest.

\section{Acknowledgments}

This work was financially supported by Agencia Nacional de Promoción Científica y Tecnológica (ANPCyT) and CYTED project (PANXTODOS P106AC0301).

\section{References}

[1] A. E. León and C. M. Rosell, "Cultivos andinos," in De Tales Harinas Tales Panes, pp. 244-294, ISEKI-Food, Córdoba, Spain, 1st edition, 2007.

[2] G. T. Pérez, M. E. Steffolani, and A. E. León, "Cañahua: an ancient grain for new foods," in Functional Properties of Traditional Foods, K. Kristbergsson and S. Ötles Eds., pp. 119-130, Springer Science+Business Media, New York, NY, USA, 1st edition, 2016.

[3] R. Repo-Carrasco-Valencia, A. A. de La Cruz, J. C. I. Alvarez, and $\mathrm{H}$. Kallio, "Chemical and functional characterization of kañiwa (Chenopodium pallidicaule) grain, extrudate and bran," Plant Foods for Human Nutrition, vol. 64, no. 2, pp. 94-101, 2009.

[4] R. Repo-Carrasco, C. Espinoza, and S. E. Jacobsen, "Nutritional value and use of the andean crops quinoa (Chenopodium quinoa) and kañiwa (Chenopodium pallidicaule)," Food Reviews International, vol. 19, no. 1-2, pp. 179-189, 2003.

[5] R. N. Curti, J. Sajama, and P. Ortega-Baes, "Setting conservation priorities for Argentina's pseudocereal crop wild relatives," Biological Conservation, vol. 209, pp. 349-355, 2017.

[6] M. C. Bustos, G. T. Pérez, and A. E. Leon, "Structure and quality of pasta enriched with functional ingredients," RSC Advances, vol. 5, no. 39, pp. 30780-30792, 2015.

[7] C. M. Tudorică, V. Kuri, and C. S. Brennan, "Nutritional and physicochemical characteristics of dietary fiber enriched pasta," Journal of Agricultural and Food Chemistry, vol. 50, no. 2, pp. 347-356, 2002.

[8] M. C. Bustos, G. T. Pérez, and A. E. León, "Effect of four types of dietary fiber on the technological quality of pasta," Food Science and Technology International, vol. 17, no. 3, pp. 213-221, 2011.

[9] M. Petitot, L. Boyer, C. Minier, and V. Micard, "Fortification of pasta with split pea and faba bean flours: pasta processing and quality evaluation," Food Research International, vol. 43, no. 2, pp. 634-641, 2010.

[10] A. Hager, A. Wolter, F. Jacob et al., "Nutritional properties and ultra-structure of commercial gluten free flours from different botanical sources compared to wheat flours," Journal of Cereal Science, vol. 56, no. 2, pp. 239-247, 2012.

[11] M. E. Steffolani, P. Villacorta, E. R. Morales-Soriano et al., "Physicochemical and functional characterization of protein isolated from different quinoa varieties (Chenopodium quinoa willd.)," Cereal Chemistry Journal, vol. 93, no. 3, pp. 275-281, 2016.

[12] D. Y. Gallego Villa, L. Russo, K. Kerbab et al., "Chemical and nutritional characterization of Chenopodium pallidicaule (cañihua) and Chenopodium quinoa (quinoa) seeds," Emirates Journal of Food and Agriculture, vol. 26, no. 7, pp. 609615, 2014.

[13] L. Alvarez-Jubete, H. Wijngaard, E. K. Arendt, and E. Gallagher, "Polyphenol composition and in vitro antioxidant activity of amaranth, quinoa buckwheat and wheat as affected by sprouting and baking," Food Chemistry, vol. 119, no. 2, pp. 770-778, 2010.

[14] J. M. Peñarrieta, J. A. Alvarado, B. Åkesson, and B. Bergenståhl, "Total antioxidant capacity and content of flavonoids and other phenolic compounds in canihua (Chenopodium pallidicaule): an Andean pseudocereal," Molecular Nutrition and Food Research, vol. 52, no. 6, pp. 708-717, 2008.

[15] U. Gawlik-Dziki, D. Dziki, M. Świeca et al., "Bread enriched with Chenopodium quinoa leaves powder-the procedures for assessing the fortification efficiency," LWT-Food Science and Technology, vol. 62, no. 2, pp. 1226-1234, 2015.

[16] C. M. Rosell, G. Cortez, and R. Repo-Carrasco, "Breadmaking use of andean crops quinoa, Kañiwa, Kiwicha, and Tarwi," Cereal Chemistry Journal, vol. 86, no. 4, pp. 386-392, 2009.

[17] S. Chillo, J. Laverse, P. M. Falcone et al., "Influence of the addition of buckwheat flour and durum wheat bran on spaghetti quality," Journal of Cereal Science, vol. 47, no. 2, pp. 144-152, 2008.

[18] F. A. Fiorda, M. S. Soares, F. A. F. A. da Silva et al., "Microestructure, texture and colour of gluten-free pasta made with amaranth flour, cassava starch and cassava bagasse," LWT-Food Sci Technol, vol. 54, no. 1, pp. 132-138, 2013.

[19] AACC, American Association of Cereal Chemists, Approved methods of the AACC, Association of Cereal Chemists, Saint Paul, MN, USA, 10th edition, 2000.

[20] C. Bruneel, B. Pareyt, K. Brijs, and J. A. Delcour, "The impact of the protein network on the pasting and cooking properties of dry pasta products," Food Chemistry, vol. 120, no. 2, pp. 371-378, 2010.

[21] L. A. Grant, D. C. Doehlert, M. S. McMullen, and N. Vignaux, "Spaghetti cooking quality of waxy and non-waxy durum wheats and blends," Journal of the Science of Food and Agriculture, vol. 84, no. 2, pp. 190-196, 2004.

[22] E. Steffolani, A. E. León, and G. T. Pérez, "Study of the physicochemical and functional characterization of quinoa and kañiwa starches," Starch-Stärke, vol. 65, no. 11-12, pp. 976-983, 2013.

[23] N. Lindeboom, P. R. Chang, K. C. Falk, and R. T. Tyler, "Characteristics of starch from eight quinoa lines," Cereal Chemistry Journal, vol. 82, no. 2, pp. 216-222, 2005.

[24] R. Tester and M. Sommerville, "The effects of non-starch polysaccharides on the extent of gelatinisation, swelling and a-amylase hydrolysis of maize and wheat starches," Food Hydrocolloids, vol. 17, no. 1, pp. 41-54, 2003.

[25] C. Collar, E. Santos, and C. M. Rosell, "Significance of dietary fiber on the viscometric pattern of pasted and gelled flourfiber blends," Cereal Chemistry Journal, vol. 83, no. 4, pp. 370-376, 2006. 
[26] A.-C. Eliasson, "Interactions between starch and lipids studied by DSC," Thermochimica Acta, vol. 246, no. 2, pp. 343-356, 1994.

[27] L. J. Symons and C. S. Brennan, "The effect of barley b-glucan fiber fractions on starch gelatinization and pasting characteristics," Journal of Food Science, vol. 69, no. 4, pp. 257-261, 2004.

[28] F. Tufvesson, M. Wahlgren, and A. C. Eliasson, "Formation of amylose-lipid complexes and effects of temperature treatment Part 1," Monoglycerides. Starch/Staerke, vol. 55, no. 2, pp. 61-71, 2003.

[29] F. A. Manthey and A. L. Schorno, "Physical and cooking quality of spaghetti made from whole wheat durum," Cereal Chemistry Journal, vol. 79, no. 4, pp. 504-510, 2002.

[30] M. B. Vignola, M. C. Bustos, and G. T. Pérez, "Comparison of quality attributes of refined and whole wheat extruded pasta," LWT-Food Science and Technology, vol. 89, pp. 329-335, 2018.

[31] A. R. Islas-Rubio, A. M. Calderón de la Barca, F. CabreraChávez et al., "Effect of semolina replacement with a raw: popped amaranth flour blend on cooking quality and texture of pasta," LWT-Food Science and Technology, vol. 57, no. 1, pp. 217-222, 2014.

[32] M. J. Sissons and I. L. Batey, "Protein and starch properties of some tetraploid wheats," Cereal Chemistry Journal, vol. 80, no. 4, pp. 468-475, 2003.

[33] M. J. Sissons, N. E. Egan, and M. C. Gianibelli, "New insights into the role of gluten on durum pasta quality using reconstitution method," Cereal Chemistry Journal, vol. 82, no. 5, pp. 601-608, 2005.

[34] T. Fuad and P. Prabhasankar, "Role of ingredients in pasta product quality: a review on recent developments," Critical Reviews in Food Science and Nutrition, vol. 50, no. 8, pp. 787-798, 2010.

[35] A. Sicignano, R. Di Monaco, P. Masi, and S. Cavella, "From raw material to dish: pasta quality step by step," Journal of the Science of Food and Agriculture, vol. 95, no. 13, pp. 2579-2587, 2015.

[36] The National Academies, Dietary Reference Intakes for Energy, Carbohydrate, Fiber, Fat, Fatty Acids, Cholesterol, Protein, and Aminoacids, Institute of Medicine of The National Academies, Washington, DC, USA, 2005. 

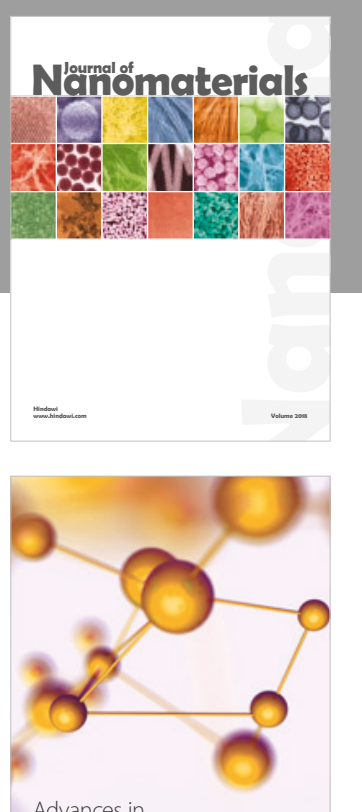

Physical Chemistry
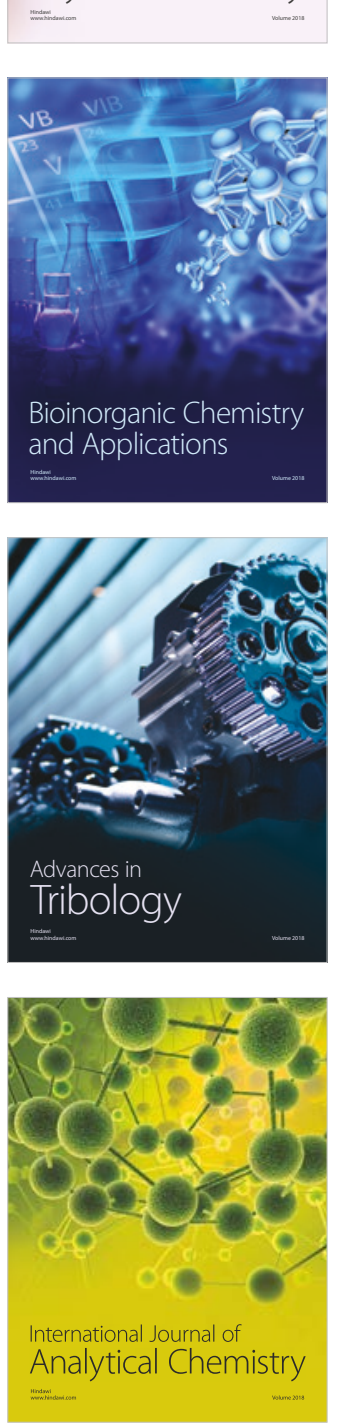

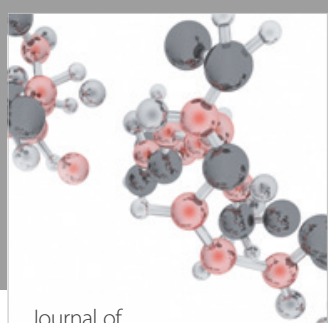

Analytical Methods

in Chemistry

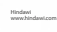

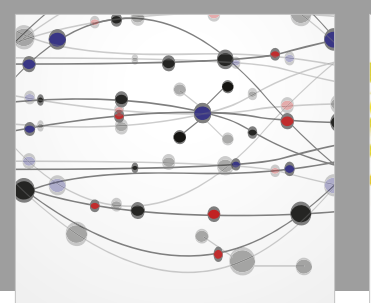

The Scientific World Journal

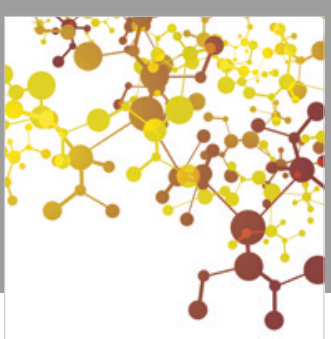

Journal of

Applied Chemistry
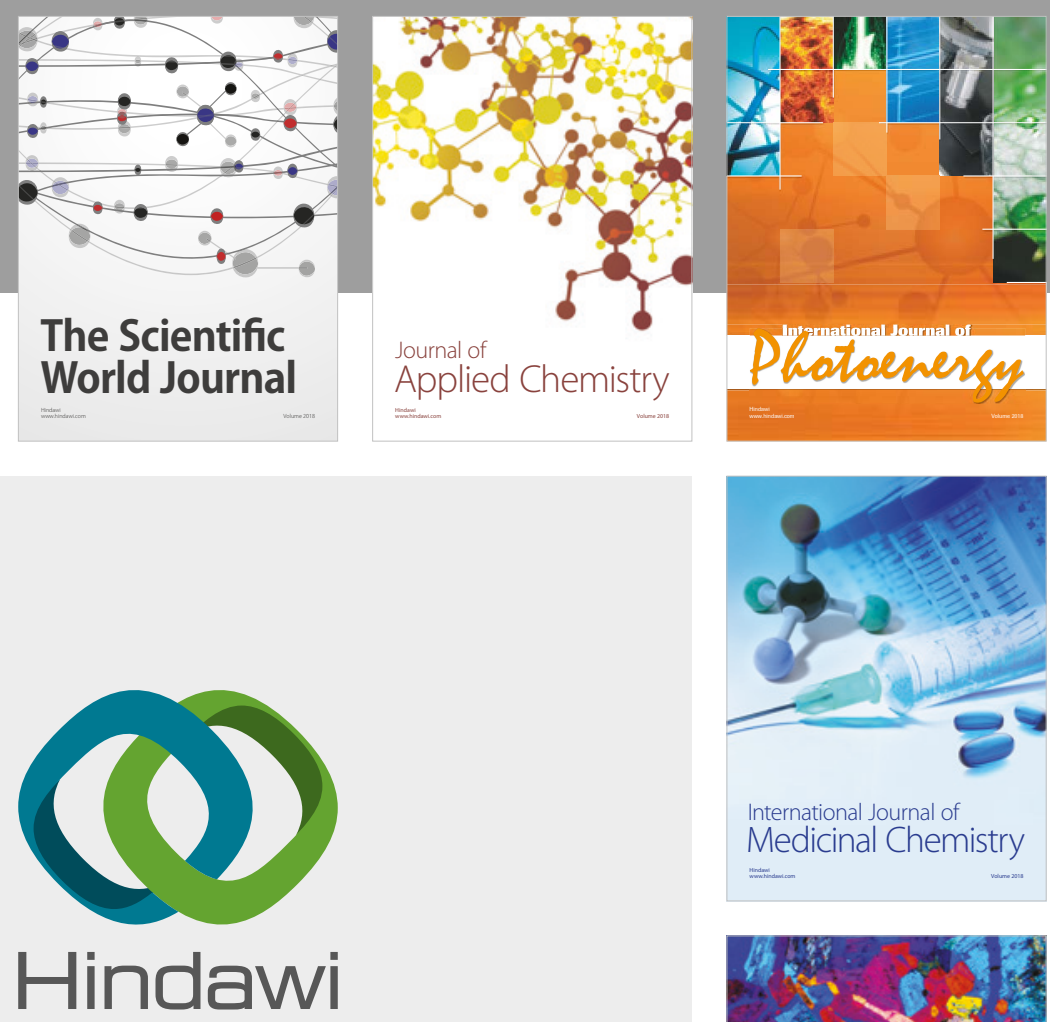

Submit your manuscripts at

www.hindawi.com
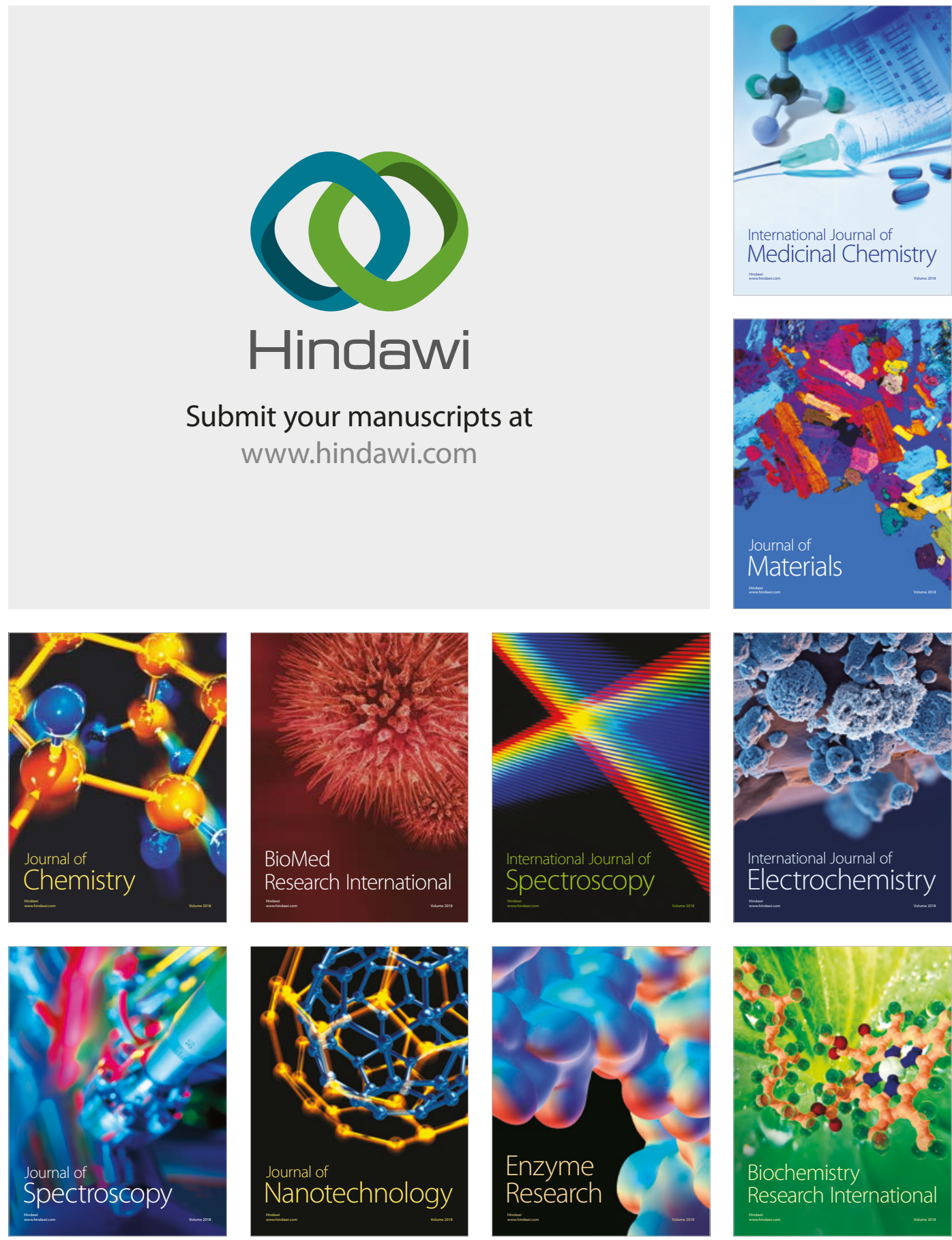
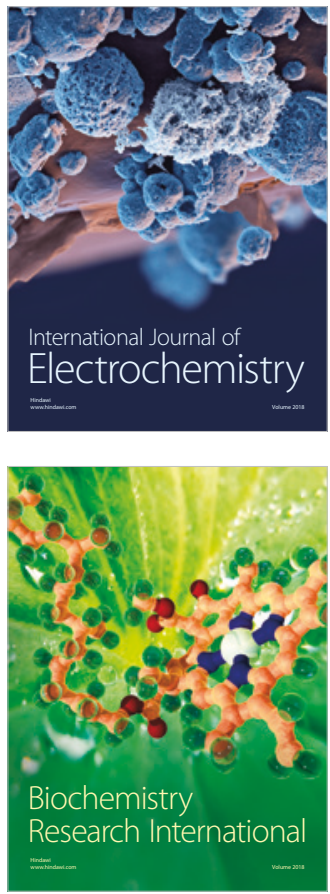